\title{
EVEN GIANTS NEED A CLUB: DOMESTIC INSTITUTIONS, MARKET SIZE, AND REGULATORY INFLUENCE*
}

IE Working Paper

David Bach

Instituto de Empresa Business School

Serrano 105

28006, Madrid

Spain

david.bach@ie.edu
DE8-116-I

$29-03-2005$

\begin{abstract}
In this paper we show that work on international market regulation has paid insufficient attention to the critical role played by domestic political and regulatory institutions. Exis ting literature emphasizes the role of market power, determined by market size, in analyzing international regulatory influence. While we do not contes $t$ the importance of market power, we introduce the notion of domestic regulatory capacity to c apture the domestic institutional side of international market regulation that previous work has sidestepped. Domestic regulatory capacity is the missing link between latent market power vested in market size and i nternational influence activated through regulatory institutions. The article employs the market size argument as a nul 1 hypothesis and contrasts it with a specification of market power that includes domestic regulatory capacity alongside market size. The two perspec tives are evaluated in a structured, focused case compar ison of i nternational regulatory dynamics in the financial securities and personal data fields.
\end{abstract}

\footnotetext{
* Earlier versions of this paper were presented at the Annual Meeting of the American Political Science Association, Chicago, IL, 2-5 September 2004, and the Faculty Research Seminar at Instituto de Empresa Business School. We would like to thank David Allen, Manuel Beccera, Ed Fogerty, Carl Kock, Joseph Pistrui, Craig Pollack, Elliot Posner, Juan Santalo, Beth Simmons, and Steve Weber for their valuable comments on earlier drafts
} 



\section{INTRODUCTION}

Two decades of domestic and international economic liberalization have transformed the character of state/market relationships, placing regulation at the center of international economic governance. Whereas factor endowments and trade rules used to be decisive, market regulation increasingly shapes the terms of competition, corporate fortunes, and national economic welfare. Who successfully exports domestic regulation and who sets international market rules is thus not only an important question for academics, but is also a critical concern for busi ness leaders, consumer advocates, and policymakers.

It is no secret that the United States long enjoyed a dec isive edge in international market regulation. Yet the situation appears to be changing: "Increasingly, Rules of Global Economy are set in Brussels," titled the Wall Street Journal. " Over the last few years, Europe and particularly the European Union has become an influential force, shaping international market rules in areas as diverse as food safety, wireless communications, environmental protection and data privacy. ${ }^{2}$ The apparently shifting pattern of influence, away from U.S. dominance and toward a more complicated situation where Europe and the U.S. score in different areas, is an obvious empirical puzzle. At the same time, it highlights a theoretical puzzle about the variables and mechanisms that determine international regulatory influence, that is the ability of a $\mathrm{j}$ urisdiction to move international market regulation closer to its ideal point.

Most existing work on this topic views market power as the principal determinant of international regulatory influence and equates market power with market size. This art icle finds support for the first premise and contests the second. The intuitive argument that underpins existing work is that the larger a domestic market relative to the global market, the greater the abil ity to shape international rules through regulatory export or negotiation. It is their economic might, in other words, that provides the U.S. and Europe with the power to shape international market regulation. Yet we contend that market size alone does not equal market power. The latent power vested in a sizeable market has to be activated and projected to shape international market rules. The ability to activate and project, in turn, depends on a jurisdiction's regulatory capacity, a variable that captures the domestic political and regulatory institutions in which markets are embedded. ${ }^{3} \mathrm{We}$ define regulatory capacity as a jurisdiction's ability to formulate, monitor, and enforce a set of domestic market rules.

\footnotetext{
${ }^{1}$ See Brandon Mitchener, "Increasingly, Rules of Global Economy are set in Brussels," The Wall Street Journal, 23 April 2002, A1

${ }^{2}$ For food safety see Young 2003, telecommunications policy see Glimstedt 2001, for environmental policy see Bretherton (1999), and for data privacy see Shaffer (2000).

${ }^{3}$ In formulating a generalizable theory, we refer to "domestic" institutions even though the European Union is more appropriately viewed as a case of multilevel governance spanning domestic and supranational spheres. See Hooghe and Marks 2000. In this system, power centers vary by issue area. Consciousness of such variation allows us to apply domestic institutional analysis to the EU as a whole and thus do justice to the importance of EU-level policymaking in certain industries.
} 
This article's principal contribution is thus a correction of existing literature. It does not refute the importance of market size but shows that market size alone is insu fficient. Gi ven a large market, the probability that a jurisdiction will be able to exert regulatory influence increases with the extent of its regulatory capacity. As a deliberate corrective, this article shares the existing literature's analytic focus o $\mathrm{n}$ the ability to shape international market rules rather than concentrating on case-to-case motivation for doing so. It $\mathrm{i}$ s clear that policymakers face considerably incentives to export domestic regulation. These range from deliberate efforts to defend the domestic regulatory status quo against international arbitrage all the way to political pressure from domestic producers for an international level-playing field (Singer, 2004; Bach, 2004). While we show in the article's empirical section why regulators sought to export specific domestic regulation, our framework does not contain a universal theory of prefere nces in the context of international market regulation. Rather, in line with existing work on market power, we examine the factors determining states' ability to influence international market regulation when they choose to do so. This also me ans that we do not consider international regulatory harmonization that results from pure market coordination, instances where neither deliberate promotion of rules nor interest conflicts occur. ${ }^{4}$

The focus on regulatory capacity and the domestic institutions that activate market power rests on historical institutionalist theory (Steinmo, Thelen, and Longstreth, 1992; Thelen, 1999). Most importantly, we build on work in comparative political economy that examines the political and economic implications of sector-specific regulatory structures against the background of broader, polity-level variation in regulatory styles and policymaking capabilities. Such re gulatory institutions constrain and enable the ability of actors to achieve their desired outcome. In the case of international market regulation, they determine the ability of large markets to translate their economic clout into political power. In addition to shedding light on critical determinants of influence patterns in international market regulation, a principal goal of this study is therefore to intensify the dialog between two closely related fields - comparative political economy and international political economy.

The paper begins with an analysis of existing International Relations literature that stresses the role of market size as a determinant of international regulatory influence. Section two defines regulatory capacity, shows how it serves to activate market power, and introduces qualitative measures for its assessment in a given industry, jurisdiction, and time. We then evaluate existing arguments privileging market size a gainst the historical institutionalist perspective with its attention to regulatory capacity in the context of two hi storical narratives - securities market regulation and the regulation of personal data flows over the last three decades. Owing to the digitalization of personal da ta and the dematerialization of securities, business in both areas increasingly takes place through sophisticated communications networks that span the glo be. Jurisdictional conflict and regulatory spillover is therefore the norm rather than the exception in these areas, making them an ideal set of cases to evaluate contrasting theoretical claims.

\footnotetext{
${ }^{4}$ This boundary condition parallels Keohane's focus on cooperation arising from patterns of discord, rather than from harmony where cooperation is analytically unproblematic.
} 
Additionally, the policy areas offer ample variation in patterns of influence across jurisdictions and time. Whereas the U.S. long dominated international securities regulation, Europe has in recent years made considerable inroads. In the case of personal data, the U.S. and the EU have pursued opposite regulatory strategies but the Europeans have been far more successful at exporting their model to third countries. These historical narratives, therefore, are uniquely suited to intensify the di alog of theory and evidence that is crit ical to she d light on the plausibility, strengths, and weaknesses of the proposed theoretical framework. Subsequently, we review the market size and regulatory capacity perspectives in light of the evidence. We find that regulatory capacity is indeed a critical factor in the activation of market power. As expected, we do not find that market size is irrelevant. But market size alone neither offers a complete nor a compelling explanation of the cases. Coupling market size with regulatory capacity, by contrast, yields a more nuanced view of $m$ arket power and handles the complexity of the empirical realities. The final section draws conclusions for research, business, and public policy.

\section{MARKet Size: Existing Arguments AND EXPECTATIONS}

Arguing that military power is only one way through which hegemons advance their interests, James and Lake (1989) call market power "the se cond face of hegem ony." Hegemons rely on their large markets to change relative prices and thus tilt the international economy in their favor. Working in this tradition, Drezner applies the argument to the case of international market regulation. Emphasizing the decisive role played by great powers in international regulatory dynamics, Drezner defines them as "governments that posses large internal markets" (Drezner, 2004:3). Large markets, he argues, have a "gravitational effect on producers - the larger the economy, the stronger the pull for producers to secure and exploit market access (Drezner, 2004:5)." Given the international distribution of economic power, Drezner views only the U.S. and the EU as currently possessing sufficiently large domestic markets to project influence. When the two heavyweights' interests converge, regulatory harmonization is po ssible. When they are at odds, competition between two rival camps splits global markets.

A second group of sc holars view international market share in a $\mathrm{n}$ industry as the decisive determinant of international regulatory influence, rather than the overall size of the domestic economy. Aggarwal (1985), for example, attributes U.S. power in international textile bargaining to the size of the U.S. textile industry and domestic textile demand. Similarly, in their examination of international banking regulation, Oatley and Nabros (1998) argue that U.S. and British banking regulators were able to impose their preferences for capital adequacy standards on other advanced industrial countries because the U.S. in p articular enjoyed "financial market power" stemming from its international market share in banking and finance.

Richards' analysis of the effects of market size on regulatory dynamics in the international civil aviation industry is particularly illustrative as he explicitly models a sequential bargaining process that is frequently alleged but rarely specified in the li terature. International regulatory 
negotiations, he argues, take place in the shadow of the reversion point, that is, the set of market place rules that a market reverts back to in the absence of a new international agreement. States that have "market power to unilaterally define market place rules" are "able to dictate the reversion point... and are thereby able to define the choice set available to foreign governments" (Richards, 1999:13). This alters the calculus for bargaining partners, leading them to ac cept international rules that might favor their competitors. ${ }^{5}$ After World War II, the physical scope of the British Empire at a time when planes needed to land frequentl y and refuel gave British negotiators a bargaining edge over their U.S. coun terparts. Once technological change had reduced the value of overseas possessions, however, the U.S. could draw on its much larger share of the international commercial aviation market to sha pe market rules according to its preferences. In each instance, Richards argues, market size and the resulting ability to define the reversion point determined whose preferences would be reflected in international rules.

Previous research has cl early established the importance of market size for int ernational regulatory influence. Yet none of the authors cited above opens up the domestic arena where most market regulation takes place. Vogel's work is an important corrective in this respect and provides a stepping stone for the domestic institutional argument developed below (Vogel, 1995; 1997). Like Drezner, Vogel views large internal markets as exhibiting a gravitational effect. In addition to the passive regulatory "pull" of large markets, however, Vogel also highlights the conscious "push" of domestic rules into international markets by domestic stakeholders. In competitive international markets, strict regulatory standards can put local producers at a disadvantage. Local producers, therefore, have strong incentives to seek an externalization of those rules to achieve a level-playing field. Particularly in areas such as environmental, labor, or consumer protection regulation, local producers become natural allies of activists seeking stricter international standards. The resulting coalitions of "baptists and bootleggers" lobby for import restrictions or other trade sanctions to affect foreign regulatory dynamics (DeSombre, 1995; 2000). Provided the domestic market is sufficiently large, foreign producers lobby their own governments to adopt stricter standards or at least dro $p$ their opposition to similar demands by local activists. Through this simultaneous "pull" and "push ," large markets thus exert considerable influence over international market regulation.

By focusing attention on the domestic political dynamics that und erpin international market regulation, Vogel and DeSombre clearly move beyond authors who treat the domestic arena as a black box. Ye t while adding domestic politics and preferences to the analysis, they share the emphasis on material aspects of domestic markets that informs other existing studies. Market size is seen as the ultimate determinant of international regulatory influence. Pa tterns of international influence, in turn, should reflect underlying differences in market size across the principle protagonists. Sudden change in influence patterns is unlikely, as international market share and the balance of market power tend to shift gradually.

\footnotetext{
${ }^{5}$ See also Oatley and Nabors 1998 and Gruber 2000.
} 
Summarizing the core proposition of existing work, we can thus formulate a null hypothesis for this study:

$H_{0}$ : International regulatory influence is a function of domestic market size.

Two corollaries capture derivative propositions and reinforce the null hypothesis:

$C_{0}$ 1: When two large markets have opposing preferences, international regulatory stalemate ensues.

$C_{0}$ 2: Sudden shifts in patterns of international regulatory influence are due to exogenous shocks, such as technological change or market fusion.

The market size approach provides a clear benchmark for st udies of i nternational market regulation. Yet scholars emphasizing market size have neglec ted the critical role of domestic institutions. Drawing on historical institutional theory, the following section develops a corrective to existing arguments. Market size does not equal market power. Instead, market power is a composite of market size and the domestic regulatory institutions that translate market size into regulatory influence.

\section{The Activation of Market PoWer through Regulatory CapaCity}

In order for regulators from large markets to promote their domestic agenda internationally, they must have suffi cient institutional capacity to monitor and enforce their preferred rules. By focusing on the role of domestic regulatory institutions, our argument draws on critical insights from and com plements the market size literature in order to construct a causal model that integrates the importance of regulatory authority with the coercive power of markets.

The intuition behind the argument rests on the micro-institutional revolution that has swept political economy over the last two decades. We start with the fundamental insight of historical institutionist theories that political institutions enable and constr ain political strategies and outcomes (Steinmo, Thelen, and Longstreth, 1992; Zysman, 1994; Thelen, 1999). Following the "rediscovery" of the state in comparative politics, the idea that state capacity structures the realm of possible policy outcomes has become a stapl e of comparative analysis. As Evans, Reuschemeyer, and Skocpol explain, studies of state c apacity attempt to identify "specific organizational structures the presence (or absence) of which see ms critical to the ability of the state authorities to undertake given tasks. In turn, the presence or abse nce of organizational structures is connected to past state policies, thus underlining the need for historical as well as structural analysis if specific state capacities and incapacities are to be un derstood" (Evans, Rueschemeyer, and Skocpol, 1985:351). Policymakers rely on the administrative tools of the state to implement and enforce their goals. The configuration of these tools then constitute 
incentives and constraints that shape the range of viable policy options available to policymakers. Rarely is a sing le institution decisive for a particular outcome. Instead, institutional complementarities - interlocking and mutually reinforcing micro-institutions such as pensio $\mathrm{n}$ systems, vocational training programs, unemployment regimes, and financial systems - structure political and economic change in predictable patterns (Amable, 2000; Hall and Gingerich, 2002; Mattli and Büthe, 2003). This institutional fabric, in turn, not only molds the process of economic policymaking but also shapes b usiness strategies, national production profiles, and increasingly constitutes the basis of competitive advantage (Hall and Soskice, 2001; Porter, 1990).

In addition to highlighting the role of state capacity, work in com parative political economy underscores the importance of time and ti ming for the development and deployment of these resources (Pierson, 2000; 2004). The Weberian administrative state was not born in an instant but is ra ther the product of continuous institutional layering (Thelen, 2003). State capacity deployed in time $\mathrm{T}=1$ tends to have been constructed at a previous point $\mathrm{T}=0 \mathrm{a}$ nd the corresponding institutions were naturally conceived with the problems of that time mind. The sequencing of state transformations plays a critical role in the emergence of state capacity and therefore the character of state capacity is heavily influenced by the legacy of its birth environment. For instance, the progressive era reforms which establi shed an independent civil service in the U.S. were critical to the completion of the New Deal forty years later (Skowronek, 1982). While states often attempt to construct new administrative capacity in the face of policy demands, existing institutional legacies frequently delimit the range of potential reform and structure actual responses (Pierson, 1993).

The micro-institutional revolution in comparative politics has also spurred new insights in the study of comparative market regulation. Polities systematically differ in their regulatory styles due to variation in administrative law, l egal procedure, the structure of the judiciary, and the ability of the private sector to carry out public objectives (Badaracco, 1985; Vogel, 1986; Newman and Bach, 2004). These differences then shape market dynamics. Kagan, for example, has identified a distinct U.S. approach that rests on adversarial legal wrangling among invested interests, delegation of $\mathrm{p}$ olicymaking authority to independent regulatory agencies, and contestation of publicly exercised authority in court (Kagan, 2001). Domestic market regulation, in short, is characterized by the regulatory tools policymakers have at their disposal and is shaped by the institutional environments in which markets are embedded.

These various insights from the field of comparative political economy are clearly relevant for problems of international market regulation confronted by scholars of International Relations. Given that state capacity structures the ability of policymakers to formulate and adopt specific policies in the domestic arena, it seems self-evident that institutional structures have important effects on policies aimed to project domestic rules internationally. We i ntroduce the notion of regulatory capacity to focus analytic attention on the particular institutional tools and capacities most relevant to the area of market regulation. Regulatory capacity, like the larger universe of state capacity, evolves over time and is the product of specific historical political circumstances. As such, we should expect regulatory capacity to naturally vary across regulatory domains and 
jurisdictions. We define regulatory capacity in the context of international economic governance as a jurisdiction's ability to formulate, monitor, and enforce a set of domestic market rules. Regulatory capacity, in turn, increases the likelihood that these jurisdictions will be able to move international outcomes closer to their ideal point.

Jurisdictions with large markets rely on their institutional resources to make demands on foreign jurisdictions. Those jurisdictions, in turn, a djust their regulatory regime when they perceive the cost to their national economy of resisting as greater than the c ost of adjustment (Simmons, 2001). Regulators making international demands can "punish" a failure to adjust by imposing a broad variety of penalties, particularly on foreign firms, including reputational costs associated with condemnation, official regulatory fines, or even exclusion from the domestic market. The size of the domestic market controlled by such regulators certainly determines the extent of potential costs to resistance. It does not determine the actual cost of non-adjustment, however, because the probability of suffering penalties has little to do with market size but rather with the credible threat of di scovery and enforcement. Critical, then, in the influence equation is the foreign jurisdiction's perception of the demand-making regulator's ability to monitor and punish inaction. Since regulatory capacity plays a critical role in determining the probability that a regulator can monitor and enforce their rules, it is the missing link between market size and international influence. ${ }^{6}$

The process of making regulatory demands on foreign jurisdictions, monitoring compliance, and sanctioning can vary considerably in its form. On o ne end of the spectrum we find pure unilateralism, instances where domestic regulators independently craft and implement rules with extra-territorial reach (Fox, 1997; 2000). Classical multilateral bargaining in the context of international regimes lies on the other end of the spectrum (Richards, 1999; Cowhey and Richards, 2000). In-between there is a vari ety of ot her forms, including transgovernmental regulatory networks (Slaughter, 1997; 2004) and bilateral ad-hoc agreements between leading jurisdictions (Shaffer, 2002; Pollack and Shaffer, 2001). Analyzing and comparing the exertion of regulatory influence through these different channels is beyond the scope of $t$ his study. The character of regulatory influence exertion is likely to vary across channels. Without regulatory capacity, however, it seems unlikely that market power can be effectively deployed to shape international market regulation, regardless of the channel.

It is clear from the preceding discussion that regulatory capacity is a mul tidimensional phenomenon. In other words, it is a composite of different domestic institutional attributes. At a minimum, regulatory capacity consists of regulatory expertise, regulatory coherence, and the extent of statutory sanctioning authority. Isolating these components allows us to construct qualitative measures of regulatory capacity across jurisdictions, sectors, and time. We model the relationship among the three components in a multiplicative fashion, where a score of ze ro on any one dimension would produce an overall score of zero. Figure 1 shows the multidimensional

\footnotetext{
${ }^{6}$ For the importance of political institutions to the provision of credible commitments see North and Weingast 1989
} 
character of regulatory capacity and highlights the continuum on each axis. Let us briefly elaborate each dimension.

Figure 1: The Three Dimensions of Regulatory Capacity

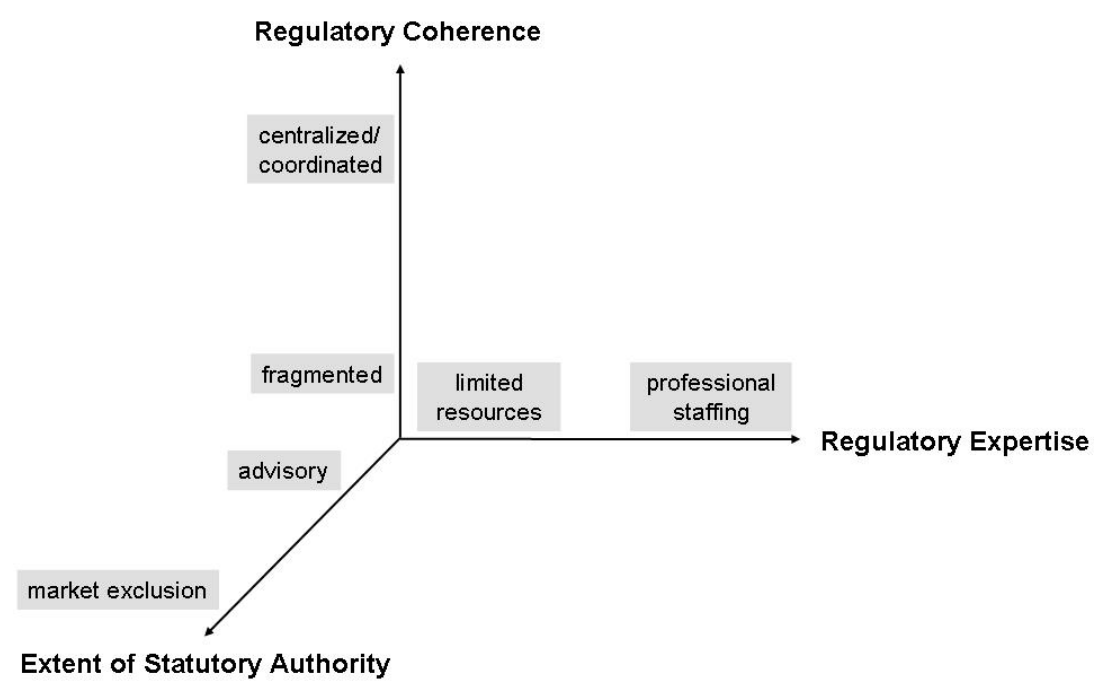

Regulatory expertise encompasses the ability to i dentify regulatory challenges, develop policy solutions, implement these solutions, and provide competent monitoring. At a minimum, developing an international regulatory strategy requires staff with sufficient training to identify areas of concern within the domestic economy and to enforce policy solutions on third countries. Comprehensive budgetary resources, experience due to y ears in existence, and a high level of professional staffing thus all demonstrate regulatory expertise. ${ }^{7}$ Regul ators with few internal resources and minimal staff find it difficult to formulate international initiatives and press their agenda against foreign jurisdictions. Those with substantial experience and staffing, by contrast, are likely to have the institutional knowledge and legitimacy to $\mathrm{pl}$ ay the role of pol icy entrepreneur. ${ }^{8}$

Regulatory capacity also requires the coherence of regulatory authority in a policy domain. Coherence depends on a clear delegation of regulatory authority in a policy domain so that multiple agencies are not vying against one another to define the regulatory agenda. All else being equal, the more coherent regulatory authority is, the easier it is to formulate externalization strategies and the more credible the commitment to monitoring and enforcem ent. ${ }^{9}$ Third

\footnotetext{
${ }^{7}$ For promising efforts to measure a regulator's power along these dimensions, see Gilardi 2002.

${ }^{8}$ Carpenter 2001 examines the importance of expertise for bureaucratic entrepreneurship.

${ }^{9}$ The importance of the coherence variable is tested and confirmed in a large sample statistical setting in Mattli and Büthe 2003.
} 
countries have little incentive to adjust their domestic rules, if the re gulator demanding adjustment is competing at home with other agencies that pursue rival strategies. The importance of regulatory coherence should not be confused with the potential bargaining power conferred to international negotiators serving contested national interests. Following the two-level game logic presented by Putnam, international negotiators may indeed find their bargaining position strengthened when they can employ squabbling domestic actors to $\mathrm{c}$ onstrain their ability to compromise (Putnam, 1988; Milner, 1997). The coherence concept, by contrast, captures the idea that a sing le actor can claim auth ority to represent a jurisdiction at the international level, regardless of the number of dom estic interests they might represent. In general, regulatory coherence should be greater when regulatory authority for an issue area has been delegated to a specific regulatory body with the power to shape and enforce market rules (Gilardi, 2002).

Finally, a crit ical determinant of regulatory capacity is the extent of statutory authority that regulators command. As noted above, regulatory capacity depends on the ability to punish those that do not adjust. The extent of statutory sanctioning authority can be identified in facilitating legislation for a regulatory domain. The most straightforward means to punish non-adjustment is to ban market entry, that is, to selectively exclude foreign firms from the domestic market. Agencies may also have the authority to fine foreign firms or serve a s ombudsman capable of exacting reputational costs. Regulators that lack the power to punish inaction have diminished ability to export their domestic regulation because foreign jurisdictions have no incentive to adjust. The pol itical and institutional ability to leverage market access to achieve international compliance is thus critical.

As noted above, we model the relationship of re gulatory capacity's three dimensions in multiplicative - as oppo sed to additive - fashion. In tuitively, a void in regulatory expertise, a total lack of statu tory authority to sanction, or complete regulatory incoherence implies the absence of regul atory capacity. A hy pothetical score of ze ro on any one dimension, in other words, leaves overall regulatory capacity at zero. More realistically, the multiplicative character of regulatory capacity suggests that scoring well on all three dimensions is more conducive to commanding substantial regulatory capacity than high marks on just one or $t$ wo. Figu re 2, for instance, sketches a hypothetical situation where jurisdiction $J_{1}$ would command greater overall regulatory capacity than jurisdiction $J_{2}$ despite scoring lower on both regulatory expertise and regulatory coherence. The re ason is that jurisdiction $J_{1}$ has considerably greater statutory authority and can t hus more effectively promote its interests, even though others may have greater expertise. 


\section{Figure 2: Comparing Regulatory Capacity}

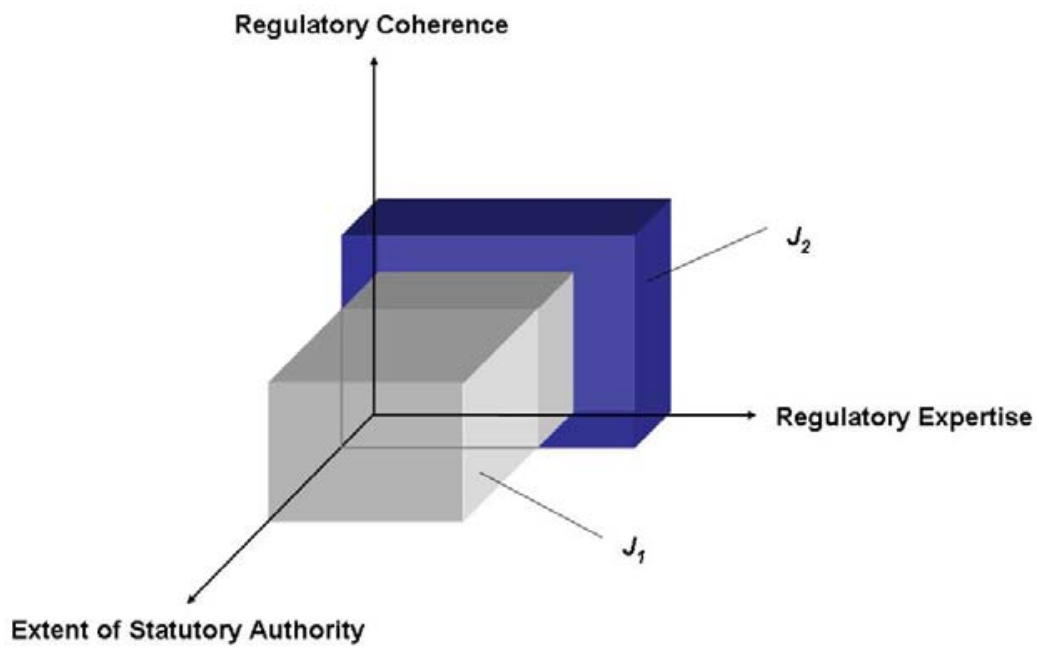

With a more robust conception of regulatory capacity, it is possible to articulate a core hypothesis in clear contrast to the null hypothesis stressing only market size:

$H_{1}$ : The greater a jurisdiction's regulatory capacity in an industry, the greater its ability to activate power vested in its market size to shape international market rules according to its preferences.

A jurisdiction's ability to promote its rules internationally depends on i ts domestic regulatory institutions. These institutions underpin a jurisdiction's capacity to monitor and enforce its rules and thereby provide the resources necessary to stimulate regulatory adjustment abroad. H1 also leads to a set of corollaries in clear contrast to those from the null hypothesis presented above:

$C_{1} 1$ : Jurisdictions with greater regulatory capacity may be able to shape international market regulation even when there is relative parity in market size.

While existing arguments focusing on market size predict opposing camps and rival rules in the case of relative market parity, we argue that discrepancies in regulatory capacity can decidedly tilt the balance toward one camp as regulatory capacity can impose non-adjustment costs even on comparably large markets. Issue hegemony may thus result despite preference conflicts among the great powers.

$C_{1}$ 2: Shifts in international regulatory influence are lagged against domestic institutional change in large markets. 
The distribution of international regulatory influence may not only shift in response to exogenous technological or market shocks, as existing work focusing on market size asserts, but rather can be due to institutional or political reform within leading jurisdictions that alters their regulatory capacity in a given industry. This means that influence may increase as market size stays constant but regulatory authority grows.

In order to scrutinize the importance of regulatory capacity for market power we examine the arguments in two historical narratives - international securities and transborder personal data flows. Owing to the transnational character of these industries, the chance of regulatory conflict is high and the two therefore represent ideal cases for examining international market regulation. Additionally, over the thirty-year period under study international securities and personal data regulation offer significant across and with-in case variation. In the securities case, the U.S. successfully projected regulatory influence in the 1980s but has seen its dominant position erode since the late 1990s. In the case of data privacy, Europe promoted its rules throughout the 1990s and only recently has been challenged in the area of nati onal security-relevant personal information. The cases also incorporate varying levels of regulatory capacity as both the U.S. and Europe reformed domestic regulatory institutions during the time period. Finally, the sectors represent substantively vital economic activity for the U.S. and Europe, the regions on which we focus. A lot was therefore at stake, and governments consequently sought to shape the rul es governing international markets in their favor as best as they could.

\section{From US DOMINANCE To Transatlantic Dialog: THE CASE OF SECURITIES REGULATION}

The value of cross-border financial flows has reached staggering levels (Simmons, 1999). At the same time, the ability to attract investment and he cost of fi nancing has become critical determinants of national and regional competitive advantage. Financial market regulation then is perhaps the most important segment of international economic governance. There is 1 ittle disagreement that the U.S. is home to the world's largest and most vibrant financial markets, and that U.S. banks, brokerages, and securities firms have dominant international positions. Simmons speaks for many when she concludes that "the United States is hegemonic in finance in the sense that it is costlier to alter its preferred regulatory innovation than to try to change the policies of the rest of the world" (Simmons, 2001:595). America's vast financial markets, in short, not only make conscious regulatory export rational; they are also the reason why such a strategy can work.

Indeed, U.S. securities regulation has si gnificantly impacted regulatory dynamics around the world. The diffusion of rules banning insider trading is particularly telling, as toleration of such practices is sharply at odds with American principles of transparency and investor protection. ${ }^{10}$ In 1980, only eleven of sixty-seven countries with stock exchanges banned insider trading. The

\footnotetext{
${ }^{10}$ Insider trading is "buying or selling a security, in breach of a fiduciary duty or other relationship of trust and confidence, while in possession of material, nonpublic information about the security." See http://www.sec.gov/answers/insider.htm (last accessed 26 February 2004).
} 
UK, Japan, Hong Kong, and Germany are just some of the global financial centers that lacked such rules. In sharp contrast, by 1998, eighty-three of now ninety-seven countries with stock exchanges had outlawed insider trading. In less than two decades, insider trading regulation spread from just 16 percent of markets to a remarkable 85 percent (Bhattacharya and Daouk, 2002).

Moreover, whereas a majority of securities markets two decades ago featured stock exchange self-regulation, central bank oversight, or $r$ egulation through finance ministries, the Am erican model anchored on an independent regulatory agency has replaced institutional alternatives in virtually all $\mathrm{m}$ ajor markets. ${ }^{11}$ As sessing regulatory reform in the UK, Japan, Germany, and Korea, Laurence concludes that "[a]ll four new agencies resemble each other in several important respects, and all were modeled, at least in part, on the [U.S. Securities and Exchange Commission]." This, he writes, is part of a "broad trend in which different countries are adopting American-style institutions of investor protection” (Laurence, 1999:647).

It would be mislea ding to vi ew such adju stments in evolutionary terms as the inevitable byproduct of the growing maturity of non-U.S. financial markets. First, regulatory emulation in Europe and elsewhere has been very costly. The interlocking ownership and cross-shareholder system is at the heart of German corporate governance, for example, makes effectively banning insider trading a real challenge. Ge rmany consequently long resisted, adopting insider trading rules only in 1994 as part of a far-reaching reorganization of its financial system (Cioffi, 2002). Moreover, several scholars argue that inside $r$ trading is not incompatible with well-functioning securities markets (Manne, 1966; Carlton and Fischel, 1983; Haddock and Macey, 1986). Second, several European markets acquired and defended their roles as leading financial centers without adopting U.S. securities regulation. The London Stock Exchange, for example, asserted its second-place position in the wo rld despite being governed unti 11988 by a private selfregulatory system. Third, while economists argue that the rise of institutional investors provided market incentives for the emulation of U.S. r egulation, European count ries appear to have stubbornly ignored such incentives, moving toward the American model only in the 1990s. In short, the diffusion of U.S. se curities regulation cannot be reduced to an intrinsic attribute of maturing markets.

Nevertheless, Europe has bee n largely on the receiving end of U.S. regul atory exports over the past three decades. Transatlantic relations in this area have long resembled a one-way street. When European regulators sought to turn the tables and force their American counterparts in the early 1990s to adopt European capital adequacy standards for securities firms, they were sharply

\footnotetext{
${ }^{11}$ From its creation in 1986 until well into the 1990s, for example, stock exchanges, central banks, and government ministries, in addition to regulatory agencies, were members of the leading international securities forum. Today, all government ministries and more than a dozen stock exchanges have been replaced by newly create regulatory agencies. In no case has an agency been replaced by a central bank, government ministry, or self-regulatory organization. SeeBach 2004.
} 
rebuffed. ${ }^{12}$ Li kewise, the U.S. v etoed European efforts to move toward mutual recognition of financial disclosure standards.

In recent years, however, European regulators have made significant inroads and have seen their international regulatory influence grow considerably. ${ }^{13}$ Consider three specific instances:

- In 2002, the EU adopted new rules mandating "consolidated regulation," i.e. oversight by a single regulator of all operations of a fi nancial conglomerate across types of financial services and jurisdictions. ${ }^{14}$ Non-EU regul ators can serve in $t$ his capacity if they meet equivalency standards. U.S. re gulators did not meet these standards and th us - under pressure from internationally-operating U.S. financial firms - had to substantially revise domestic rules to meet European demands.

- Europe successfully pressured U.S. regulators to exempt European companies listed on American exchanges - and European auditors of such companies - from certain extraterritorial applications of the newly enacted Sarbanes-Oxley Act. ${ }^{15}$

- After having long resisted European demands to permit the use of non-U.S. accounting standards by foreign companies listed on American exchanges, U.S. regulators are now actively promoting the relative convergence of U.S. GAAP and the International Accounting Standards that will be mandatory on all European exchanges starting $2005 .{ }^{16}$

In contrast to the long period of US issue hegemony in securities regulation, U.S. regulators made important concessions to meet European regulatory demands over the last few years. They exempted European firms from extraterritorial U.S. regulations and revised domestic rules to accommodate extraterritorial provisions of new European regulation. Thus, Simmons' claim that it is costlier for the U.S. to alter its domestic regulation than to get foreign jurisdictions to comply with U.S. preferences appears not to hold. What can explain past U.S. do minance and the more recent relative decline of U.S. international influence in this area?

\section{Market Size}

If U.S. international regulatory hegemony in the securities industry in the 1980 s and early 1990 s was indeed rooted in the dominance of Am erica's financial markets, a recent catching-up of Europeans might explain the current, $m$ ore balanced regulatory dynamics. Indeed, Europ ean policymakers hoped that the i ntroduction of the Euro would boost the relative standing of

\footnotetext{
${ }^{12}$ See Tracy Corrigan, "SEC and regulators deadlocked over capital requirements," Financial Times, 30 October 1992, 31, and Richard Waters, "IOSCO drops common capital rules plan," Financial Times, 11 February $1993,29$.

${ }^{13}$ The following section draws on Posner 2004.

14 "A bit of give and take," The Economist, 17 October 2002.

15 Jon Ashworth, "US regulator hints at accounting compromise," The Times, 11 October 2002, 27, and Sharon Ward, "EU hands list of corporate reforms complaints to US," The Scotsman, 1 December 2002, 3.

${ }^{16}$ Floyd Norris, "U.S. and European Securities Officials Vow Cooperation," The New York Times, 5 June $2004,3$.
} 
European markets and firms. Yet there is li ttle evidence Europe's common currency has challenged the dollar's preeminence, whether a s reserve currency, denominator of critical commodities, or for sec urities underwriting (Cohen, 2003). But more importantly, longitudinal data on relative market size appears inversely related to the patterns of international regulatory influence described above (figure 2).

Figure 2: U.S. and European Securities Market Capitalization, 1980-2001

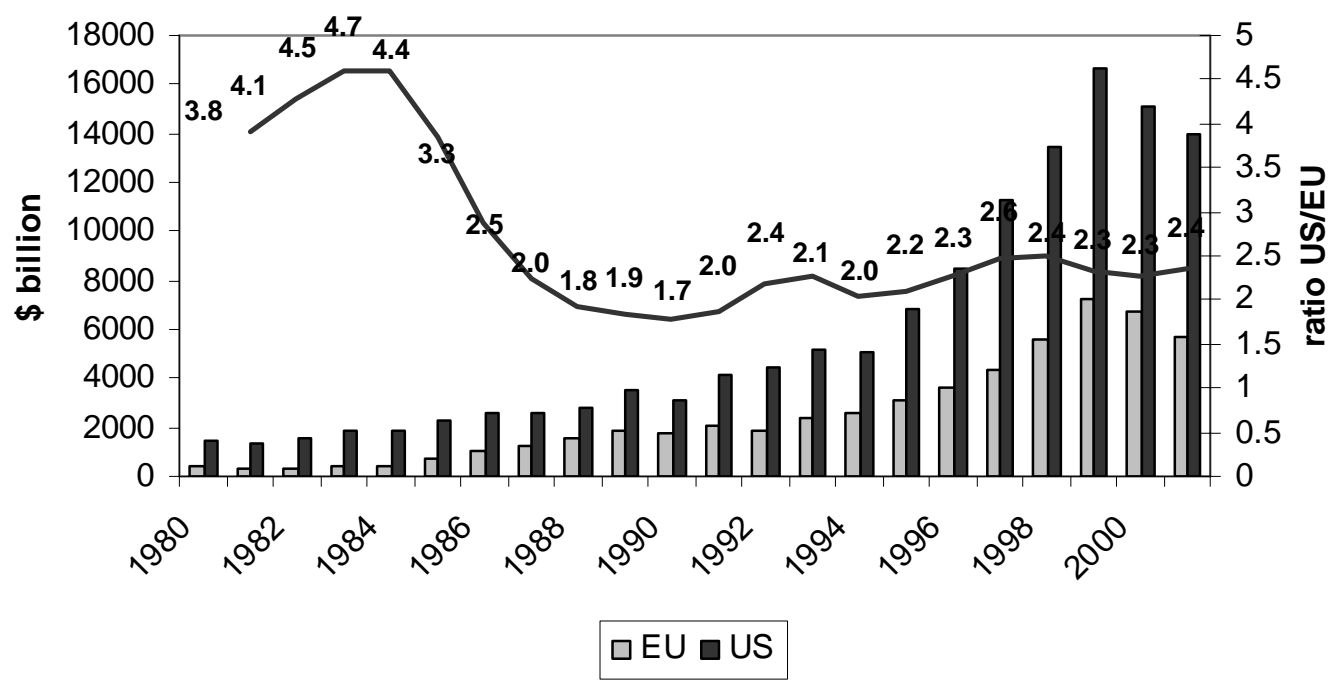

Note: the first column for each year is the sum of figures for the UK, France, Germany, Italy, and the Netherlands. The second column is the sum of U.S. markets. Ratios are two-year moving averages.

Source: Securities Industry Association Factbook 2002.

Between 1983 and 1991, the period when U.S. regul ators began the conscious export of U.S. securities market regulation, the size ratio of U.S. and major European markets fell from almost five to less than two. During the period that European markets appeared closest to America's in terms of size - the early 1990s - the U.S. frequently and effectively rebuffed European regulatory demands. Lastly - with the market size ratio largely stabilized at the two-and-a-half mark since the end of the 1990s - nothing in the data would suggest growing European influence. How can we explain strong U.S. influence at a time when it should have been fadi ng, and g rowing European influence when li ttle should have changed? Market size alone does not seem to be decisive. 


\title{
Regulatory Capacity
}

The domestic institutional view focuses attention on U.S. regulatory capacity vested above all in the SEC. Charged with investor protection by assuring fair and transparent markets, the SEC is the prototypical administrative agency of the New Dea 1. Its independent rule-making, investigative, and enforcement powers have grown steadily since its creation, and particularly since the 1960s when it obtained additional congressional authority to wage a crusade against illegal insider trading. One influential U.S. senator has called it "the strongest single unit that I know in the federal government." 17 Located at the center of a dom estic epistemic community of specialized securities lawyers and academics, the Commission has vast expertise at its disposal. In short, on all three dimensions of regul atory capacity, the U.S. se curities sector scores high. The U.S. was therefore well- positioned to respond to the challenges posed by the international integration of securities markets.

Financial globalization following the collapse of Bretton Woods and the abolition of $\mathrm{c}$ apital controls meant that cross-nati onal regulatory heterogeneity opened arbitrage opportunities. America, with its combination of high regulatory standards a nd attractive markets, was most vulnerable. SEC regulators felt this vulnerability acutely in the early 1980s when Swiss banking secrecy laws obstructed the prosecution of the two largest insider trading cases in SEC history. ${ }^{18}$ In the words of one Commissioner in 1983 (Longstreth, 1983:1610),

\begin{abstract}
Leadership in developing an appropriate international system of securities regulation will present an important challenge to the Commission in the years ahead. As transactions become easier to accomplish abroad, the Commission will become increasingly tempted to lower its standards of investor protection in order to prevent the flight of securities transactions beyond its reach. The trick wi ll be to enco urage the securities regulators of the other major trading nations to develop systems that provide protections to investors substantially similar to those provided in this country while trimming away regulations that are not essential to assure those protections.
\end{abstract}

Drawing on its substantial regulatory expertise, its considerable statutory authority, and the attractiveness of U.S. markets to foreign investors, the SEC devised a carrot-and-stick strategy for regulatory export. First, it publicly toyed with the idea of excluding anyone from U.S. markets who did not voluntarily wave foreign legal privileges. ${ }^{19}$ Again st the backdrop of this stick, the SEC approached foreign authorities to negotiate bilateral Memoranda of Understanding $(\mathrm{MoU})$ to facilitate information sharing and enforcement assistance in the figh $\mathrm{t}$ against crossborder securities fraud. Twenty years later, a dense network of MoUs has become the bedrock of regulatory cooperation in the industry. ${ }^{20}$ It was after this initial muscle flexing that the SEC endorsed the creation of IOSCO as a forum for securities regulators. Thus, rather than passively

\footnotetext{
${ }^{17}$ Senator William Proxmire of Wisconsin, as quoted in Laurence 1999, p. 660.

${ }^{18}$ For an account of these two cases - St. Joe Minerals Corp. and Santa Fe International - see Bach 2004.

${ }^{19}$ SEC regulators floated this "waiver-by-conduct"-idea publicly trough a rule-making notice and a law review article. See Fedders, et al. 1984

${ }^{20}$ More than 250 bilateral MoUs were in force in 2001 . The SEC is signatory to about fifty, making it the largest single network hub. See Bach 2004.
} 
relying on the draw of U.S. markets, the SEC has employed its regulatory capacity to proactively shape international rules according to its preferences.

European securities markets have not surpassed the U.S. There is also no indication that the U.S. has lost regulatory capacity. What then explains the trend toward a new tr ansatlantic balance? European countries did not command extensive regulatory capacity during the 1980s and into the 1990s. In key markets, independent regulators did not exist or had just been created. In several cases, stock exchanges or lower-level finance ministry officials represented European countries within IOSCO. Where i ndependent regulators did exist, they often had few personnel, little expertise, and limited enforcement powers. Most importantly, there was scant coordination among European regulators. However, a series of i nternal regulatory reforms has significantly boosted Europe's regulatory capacity, enabling it to influence international dynamics (Jabko, 2004; Posner, 2004).

Europe's move away from various forms of self- and ministerial regulation and toward SEC-style independent agency regulation is well-documented (Moran, 1994; Cerny, 1989; Lütz, 1998). The EU's Investment Services Directive merely formalized the process, requiring all member states to create independent regulators - a process completed in 1994 after Germany's reforms. In the middle of the 1990s, cooperation among these regulatory agencies intensified. Iron ically, the form of regulatory cooperation spearheaded by the SEC became the basis of these efforts. An original set of bi lateral MoUs were replaced by a multilateral MoU in 1997, and European regulators created the Forum of European Securities Commission (FESCO) as Europe's IOSCO equivalent. While technically not an EU body, FESCO became increasingly important for the coordination of European securities regulation and cross-border securities law enforcement.

Cognizant that financial market integration in Europe was lagging behind expectations, the European Commission pressed for further reform. A committee chaired by Alexandre Lamfalussy recommended sweeping changes, including the formal incorporation of FESCO into EU policymaking. Renamed the Committee of European Securities Regulators (CESR), the group has bee $n$ strengthened considerably and has become a formal pillar of a $n$ integrating European securities regime. It is through this institutional arrangement that European regulators have been a ble to coordinate positions with the European Commission on issues suc $h$ as consolidated regulation, the U.S. Sarbanes-Oxley Act, and the mandatory use of In ternational Accounting Standards in Europe that paved the way for an international agreement, and to backup regulatory demands with possible sanctions ranging all the way to market exclusion.

In sum, while the introduction of the Euro has neither flipped the market size gap to the U.S. nor fully integrated Europe's various securities markets, the last few y ears have witnessed a considerable integration of European securities regulation that has boosted regulatory capacity. Paradoxically, these reforms have in no small part grown out of previous U.S. regulatory export. The global triumph of the SEC model of regulation through powerful independent agencies and efforts to link regulators through MoUs and multilateral forums have provided Europeans with the building blocks of regulatory capacity. The simultaneous development of regulatory capacity 
within each member state and clo se integration across European markets has e nabled Europe to deploy market power in the securities field, undermine SEC hegemony, and bring about a more balanced transatlantic dynamic.

\section{European Leadership in the Digital Economy: the Case of Data Privacy}

With the rise of technologies such as the Internet, personal data can now be digitally transmitted instantaneously across the globe at almost no cost. Companies and governments wish to employ such data to segment markets and enhance security. These efforts, however, confront unique national regulatory environments that have evolved over the past thirty years (Bennett, 1992). In the 1970s, a g roup of Europ ean countries, including Germany and France, adopted comprehensive legislation that established clear privacy principles for the public and private sector enforced by independent regulatory agencies. An other set of countries that included the U.S. focused instead on threats posed by public sector data use only, relegating private sector issues to industry self-regulation (Schwartz and Reidenberg, 1996).

In the last ten years, however, the EU has dominated global privacy debates and has effectively promoted the comprehensive model. Passed in 1995, the EU data privacy directive required that all member states adopt comprehensive legislation. Additionally, the directive includes an extraterritorial provision that limits the transfer of personal information from Europe to third-countries that do not have adequate privacy legislation (Simitis, 1995). Five member states - Belgium, Greece, Italy, Portugal, and Spain - passed data privacy rules because of the directi ve. Additionally, over twenty non-member states have adopted comprehensive rules. All members of the OECD - except for the U.S. - now have comprehensive rules in place or pending in their legislatures. I $\mathrm{n}$ total, nea rly thirty countries from five continents have em ulated European standards (Council of Europe, 2004).

Although the U.S. has wage d a vocal international campaign against Europe's approach, it has not been able to contain the spread of European rules. Seven countries - including key markets such as Japan, Canada, and Australia - that had previously shared the U.S. system of protection have adopted the EU com prehensive system. Eu rope even forced the U.S. itself to make concessions. After considerable transatlantic tensions, the two sides settled the dispute about the (in-)adequacy of American rules through the adoption of the so-called Safe Harbor agreement. The agreement requires that U.S. firms active in European markets abide by EU rules even when data is processed in the U.S. ${ }^{21}$ Faced with higher operational costs, it is unl ikely that multinational companies will maintain dual data processing standards for their international and U.S. clients. Whi le the U.S. c ontinues to st all on reforming domestic data privacy rules, European regulations have thus become the de-facto international standard.

\footnotetext{
${ }^{21}$ As of 2004, nearly 600 U.S. companies have signed on to the Safe Harbor agreement, including such high-profile companies as IBM, Marriott, and Microsoft. These firms pledge to abide by EU rules and permit enforcement either by the Federal Trade Commission or European data protection officials directly. See Farrell 2003.
} 
Europe's international leadership in privacy regulation awards it a strategic edge in one of the pivotal emerging areas of economic governance. Companies across a broad range of sectors view personal information as "information capital" that they can exploit to reduce risk and to customize products and marketing. Strict data privacy policies put limits on the commodification of personal information. A recent survey of leading U.S. financial services companies suggests that the free flow of information earns the financial services industry alone about $\$ 17$ billion annually (Glassman, 2000). Moreover, in the U.S., a new industry has sprung up that depends on lax personal data regulation. Some of these "data compilers" - fi rms that gather in formation from diverse sources and sell it to other firms - have bec ome billion-dollar businesses. ${ }^{22}$ Such vibrant personal data trading contrast sharply with European markets, where strict privacy rules limit the transfer of personal information. Private sector credit reporting - a huge business in the U.S. - does not exist in France, for example. Most European companies by now firmly reject the idea of releasing customer data to third parties.

Despite Europe's general dominance in the international regulation of data privacy, the U.S. has had some recent success in asserting its interests in the field of security. In a well-publicized dispute, the U.S. demanded that all international airlines provide the U.S. customs with detailed passenger records concerning those flying into the U.S. This demand conflicted with the European privacy directive, which limits the transfer of sensit ive information to countries with inadequate privacy protection such as the U.S. Aft er several rounds of heated negotiations, the EU agreed to deliver some of the requested information. ${ }^{23}$

As is evident, personal data regulation is strategically important in the information age, significantly influences market dynamics across se ctors, and h as considerable distributional implications. Given the high stakes and the extent of America's global influence in the areas of information technology and electronic commerce, why has Europe been able to export its strict privacy rules? And why after years of impotence in the policy domain has the U.S. successfully challenged European rules in the security domain?

\section{Market Size}

While Europe has developed robust markets for electronic commerce and information services over the last several years, it still trails in comparison to the U.S. What is true today is even truer for the time between 1990 and 2000, a period marked by the passage of the EU privacy directive, the onset of European regulatory export, and the conclusion of the transatlantic Safe Harbor agreement. Regardless of methodology, all estimates suggest that Europe lags behind the U.S. in international electronic commerce (Uncapher, 2000). Forrester re search group, for e xample, estimates that global business-to-consumer (B2C) e-commerce revenue reached \$657 million in 2000. Of this, the U.S accounted for $\$ 480$ million while Europe had the second largest market at $\$ 87$ million (Forrester Research, 2000).

\footnotetext{
22 "A golden vein," The Economist, 10 June 2004.

${ }^{23}$ See Paul Meller, "Europe Fights U.S. Over Passenger Data," The New York Times, 22 September 2003, C4.
} 
America's leadership in the area of e-commerce and digital information services held across markets and industries (figure 3). In critical B2C segments, the online share of transactions in the U.S. was around three times higher than in Europ e. For our purposes, the area of financial brokerage is particularly interesting, as such transactions routinely involve sensitive personal information. In 1999, more than 15 percent of all retail financial brokerage transactions in the U.S. took place over the web. In Europe, the comparable figure was 5.5 percent. Given that these two markets account for the majority of such transactions worldwide, the figure suggest that the U.S. accounted for the lion's share of global B2C financial brokerage transactions.

Figure 3: Online Share of Different Markets, 1999

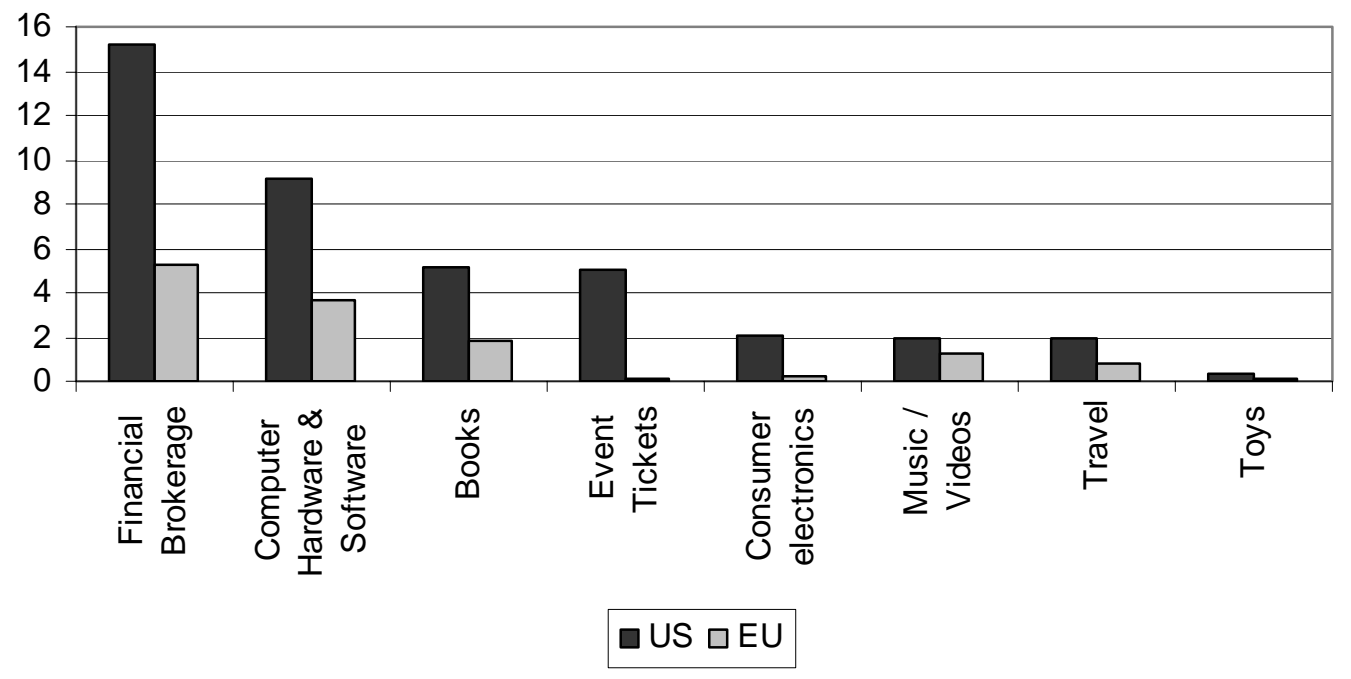

Source: The Economist 2000

Another useful measure to assess levels of personal information trade in a country is the number of deployed secure web servers, which are required to safely handle sensitive information such as credit card data. In 199 9, the U.S. led Europe wit h over 31,000 servers compared to roughly 9,000. In 2002 , Europe's 28,000 servers still trailed the U.S. with 90,000. The U.S. figure accounted for 65 percent of all secure servers in the OECD in 2002 (OECD, 2002:60). The trend line depicted in figure 4 suggests that European markets are unlikely to surpass their U.S. equivalents any time soon. 
Figure 4: Number of Secure Web Servers (SLS)

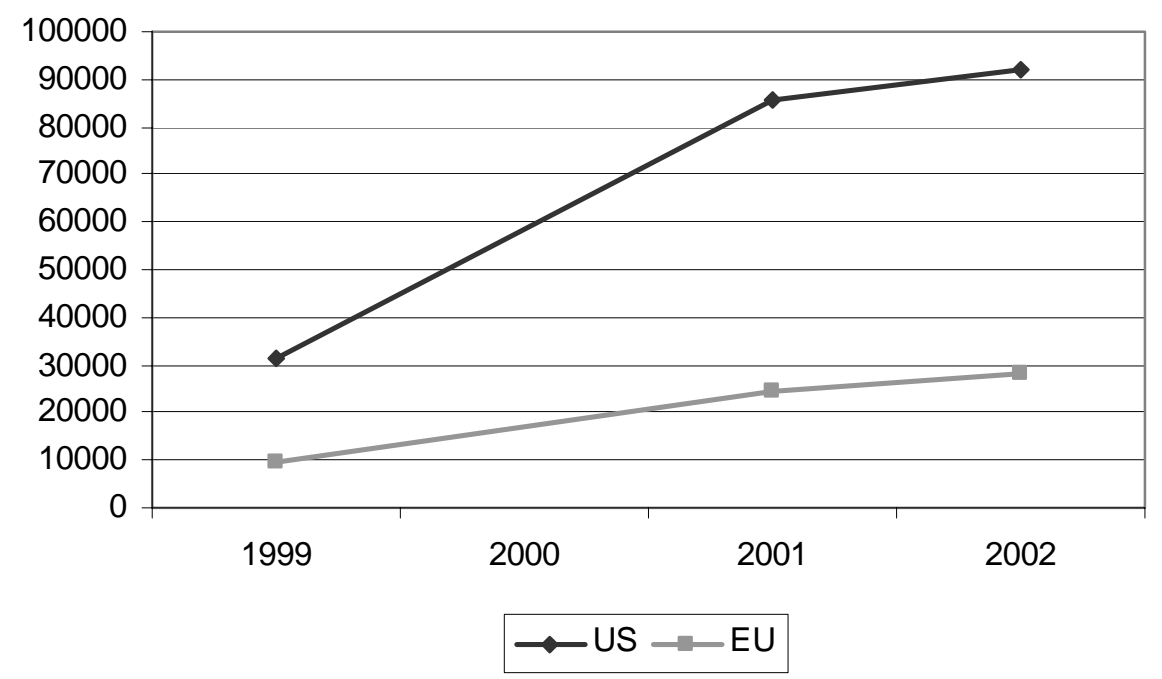

Source: OECD 2002

While the EU asserted international authority and began to successfully export its privacy standards, European markets were trailing America's considerably. At the same time that Europe dominated privacy debates, the U.S. successfully leveraged its market leadership in several key areas of e-commerce and Internet regulation, including intellectual property, taxation, trademarks, and domain names. ${ }^{24}$ Additi onally, the rec ent assertion of U.S. preferences in the dispute over airline passenger records cannot be explained by a shift in relative market size between the two regions. In short, even across information services regulatory influence has varied casting considerable doubt on the market size position.

\section{Regulatory Capacity}

Despite the limited size of European digital markets, Europe has considerable regulatory capacity in the area of privacy and an ext ensive regulatory tradition. Wit $h$ the passage of the first comprehensive privacy policy in Sweden, various European countries created independent regulatory agencies with significant monitoring and enforcement powers. Buffered from direct political control, European data protection agencies are characterized by budgetary autonomy, non-political technocratic leadership, and high levels of professional staffing. They have broad jurisdiction over issues concerned with data privacy. While the exact regulatory powers and procedures differ cross-nationally, data protection agencies have the authority to regulate the transfer of personal information to third countries, monitor and investigate complaints, review relevant legislation, leverage public opinion through the media, and at times directly punish non-

\footnotetext{
${ }^{24}$ Interestingly, these are all cases where the U.S. possessed or has created considerable regulatory capacity. See Franda 2001 and Bach 2004.
} 


\section{IE Working Paper}

compliance through administrative fines (Flaherty, 1989). They are, in short, the embodiment of substantial European regulatory capacity in this area.

The passage of the EU directive not only mandated strong data privacy regimes for all member states, but also created institutional mechanisms for intra-European coordination and external projection. For instance, the directive explicitly granted European regulators statutory authority over European market access. Regul ators can block information flows from Europe to thirdcountries that lack adequate privacy standards. $\mathrm{T} o$ this end, the directive created a transgovernmental body of member state data protection authorities - the Article 29 Group - that reviews third-country legislation, makes adequacy determinations, and more generally advises on EU data policy (Swire and Litan, 1998). So far, the Group has declared the Swiss, Canadian, and Hungarian systems as adequate, while rejecting the Australian system as too lenient. At the same time, relying on their individual authorities, national data protection agencies have fined companies that fail to meet European standards and have thereby affected interest group preferences and coalitions in third-countries. ${ }^{25}$ In sum, by institutionalizing market access control at the EU level, the pri vacy directive has significantly augmented already considerable European regulatory capacity in this area.

At the same time that the directive has increased market control, it has created the foundation for greater coherence of European regulatory efforts. The directive established a permanent secretariat for the Article 29 Gro up that is run by the European Commission. This means that national regulators are in constant contact with one another, have resources such as simultaneous translation facilities, and have gained the statu re of an official European regulatory voice. As leading experts, the group collectively interprets and monitors the implementation of the directive for the EU, and its opinions have considerable clout.

Whereas European markets feature extensive regulatory capacity along all three dimensions expertise, coherence, and statutory authority - the U.S. has little to show in this field. The decision in the 1970s to forego comprehensive privacy protection, not to cre ate a regulatory agency, and to only monitor public sector personal data use has retarded the formation of regulatory expertise and perpetuated fragm entation of a ny U.S. regulatory authority. On the federal level, the Federal Trade Commission (FTC), the Office of Management and Budget, the Department of Health and Human Services, and th e Federal Communication Commission variably claim authority for privacy concerns although none have dedicated privacy officers. There is virtually no coordination among these various public authorities, however, which limits their influence in international debates. With respect to private sector monitoring, a multitude of self-regulatory organizations carry a large share of the burden. Relying primarily on reputation mechanisms - the granting and removing of pri vacy seals - they lack the sweeping market exclusion powers of European regulator agencies. ${ }^{26}$

\footnotetext{
25 "Microsoft signs Safe Harbour following fine," Precision Marketing, 18 May 2001, 1.

${ }^{26}$ See Newman forthcoming 2005.
} 
Given the U.S.'s weak position in international privacy debates, it is interesting to note its success in the filed of airline passenger records. While changes in market size cannot account for this shift, the inclusion of regulatory capacity provides a rather persuasive explanation. While the U.S. has long lagged in regulatory capacity in the privacy sphere, it has tremendous capacity in the area of border control and airline regulation. Homeland security legislation passed since the 9/11 terrorist attacks has empowered U.S. customs officials to block flights between the U.S. and nations that fail to comply with passenger data transfer requirements. ${ }^{27}$ Additi onally, the Department of Homeland Security appointed a chief privacy officer in 2003 who is responsible for monitoring the privacy implications of U.S. security policy. When U.S. and European officials negotiated the issue of pass enger information, the U.S. thus brought a domestically empowered privacy expert to the table. While the U.S. c ertainly forced the EU to weaken its stance on cross-border personal information transfers, it is important to note that the U.S. had to make a se ries of com promises as well. The ini tial U.S. de mand required all passenger information, including such se nsitive information as meal preferences which coul d denote religious affiliation, to be transferred. EU privacy regulators strongly protested this carte blanche policy and won limits on the extent of information provided. ${ }^{28}$

In sum, despite its relatively small share of global e-commerce markets, the EU - not the U.S. has set the de-facto international privacy standard. Already enjoying considerable regulatory capacity in the personal data field at the dawn of the Internet revolution, European policymakers have augmented this capacity, integrating it at the EU level, and thereby made possible the deliberate export of the comprehensive regulatory model. While the size of U.S. markets may have been the reason why the country was able to negotiate the Safe Harbor agreement - cutting off data flows to the U.S., after all, would have pained Europeans more than in the case of, say, Chile - the U.S. has not been able to prevent the global spread of European standards. With many large U.S. companies now subjected to EU rul es through the Safe Harbor Agreement, and the U.S. fa irly isolated internationally, it may just be a matter of ti me until the U.S. has (in)formally adopted comprehensive regulation as we 11 . The case of airline passenger data, however, strikes an important counter point. Here, the U.S. has resisted European convergence pressure by leveraging its considerable regulatory capacity in customs and airline policy.

\footnotetext{
${ }^{27}$ American officials threatened to deny landing rights and fine companies six thousand dollars per passenger for failing to transfer the requested data. See Thomas Fuller, "Europe Agrees to Let US get Passenger Data," The New York Times, 18 May 2004, p. W1.

${ }^{28}$ See Philip Shenon, "US and Europeans Agree on Sharing of Airline Passenger Data," The New York Times, 17 December 2003, A18.
} 


\section{Evaluating the Arguments in Light of THE Evidence}

The historical narratives provide considerable evidence for an evaluation of the two principal arguments. The market size argument offers valuable insights. J urisdictions with sizable markets disproportionately influence international market regulation. In both cases - securities and personal data - th e U.S. and EU have play ed the dominant roles in ternationally. ${ }^{29}$ Yet the null hypothesis that international regulatory influence is determined by market size alone is not supported by the evidence. If $\mathrm{m}$ arket size alone determined influence, Europe should not have made inroads in international securities regulation and its efforts to export data privacy standards should have failed. The first corollary derived from the market size argument - that si zable markets with opposing preferences lead to international fragmentation - fares poorly as well. The case of personal data regulation powerfully refutes the claim. Europe and the U.S. have espoused sharply differing approaches to privacy protection and European rules have become the de-facto international standard, U.S. e fforts to the contrary notwithstanding. Even traditional U.S. allies such as Canada and Japan have moved toward the European model. Additionally, large U.S. companies have agreed to subject themselves to comprehensive rul es enforced either by the FTC or European data protection authorities directly. The U.S. "camp" has quickly dissipated to a group of privacy protection slackers isolated in global regulatory debates.

The second corollary derived from the market size claim fares poorly as well. The lo gic of the market size argument suggests that shifts in the pattern of international regulatory influence in an industry should generally be gradual, as market size itself changes gradually. Sudden shifts, as Richards observed for the case of international aviation markets, should be due to exogenous factors such as technological change or the fusion of previously distinct markets. Yet the evidence shows this argument to be overly restrictive. In the case of securities regulation, Europe fairly quickly and unexpectedly asserted international influence after many years on the receiving end. This shift was not due to exogenous technological change or the sudden full integration of European securities markets after the introduction of the Euro. Instead, as anti cipated in the second corollary of the regulatory capacity argument, the ability to project international regulatory influence is rooted in domestic and EU-wide institutional reforms that have augmented Europe's regulatory capacity. It was America's conscious export of SEC-st yle securities regulation and $i$ ts push for $r$ egulatory cooperation that, paradoxically, played an important catalytic role in Europe's regulatory evolution.

In general, the main hypothesis capturing the role of domestic regulatory capacity fares better. In each case, and reinforced by considerable within-case variation, high regulatory capacity over a sizeable market is as sociated with significant international regulatory influence. Jurisdictions that successfully exported domestic rules or won important foreign concessions - the U.S. in securities, the EU recently in securities, and the EU in data privacy - had domestic regulatory regimes characterized by high levels of regulatory expertise, regulatory coherence, and statutory

\footnotetext{
${ }^{29}$ Our findings thus support the argument by Drezner and others that only the U.S. and EU are currently powerful enough to be "camp leaders" in critical international regulatory debates.
} 
authority that included the ability to deny access to the domestic market. In contrast, instances of limited international influence - the U.S. in data privacy and Europe in securities markets until fairly recently - have in common relatively low degrees of regulatory capacity stemming from comparatively low levels of expertise, a high degree of regulatory fragmentation, and insufficient statutory authority.

Likewise, the claim - captured by our first corollary - that regulatory capacity can overcome a size disadvantage is supp orted by the evidence. A relati ve transatlantic balance now characterizes regulatory dynamics in international securities markets - sy mbolized by the new "EU-US Financial Markets Regulatory Dialogue" launched in 2002 - despite continuing U.S. market dominance. Similarly, despite the U.S.'s sizably larger market for information services, Europe has been abl e to dominate the international debate on data privacy protection. The evidence suggests that large markets lacking regulatory capacity may merely resist change, as in the case of the transatlantic Safe Harbor agreement, and be unable to shape a proactive international regulatory alternative. Such politics of attrition contrasts sharply to mark et size predictions that anticipate conflicting great power camps. 


\section{CONCLUSION}

This paper highlights the limits of current work, which explains international regulatory influence through material aspects of domestic markets alone. To remedy such shortcomings, we develop and offer an initial test for an argument that am ends existing work and locates the source of international regulatory influence in domestic regulatory institutions. These institutions, we argue, permit jurisdictions with large markets to activate their market size into international economic clout. Before suggesting several implications of this argument for theory and policy, it is important to emphasize the limits of the current study. While the case study method employed is well-suited to assess the sufficiency of existing work stressing the role of market size, it cannot end debate on the role of domestic regulatory institutions in international economic governance. ${ }^{30}$ In future efforts, it would be useful to work toward quantitative measures of regulatory capacity a regulatory capacity index of sor ts - that wou ld enhance the approach's utility and facilitate further testing. Furthermore, even though the study leverages cases from multiple regions at different historical moments, its focus is on transatlantic dynamics. It would be useful to extend the effort to other great powers, such as Japan and China. For example, we anticipate that the statebuilding revolution underway in China over the last decade should soon significantly alter the country's position in international economic governance, transforming it from being a mere exporter of commodities to one of market rules and standards as well (Suttmeier and Xiangkui, 2004).

It is worth highlighting two important implications of the argument, one for theory and the other for business and policy. Theoretically, our argument rests on an approach that could benefit the study of international political economy more generally. Over the last ten y ears, comparative political economy has undergone a micro-institutional revolution. Researchers have investigated how institutional configurations affect decision-making and policy outcomes. This study has applied this approach to critical issues in the international political economy field. Whi le international political economy has long recognized the importance of international institutions for international outcomes, domestic institutional variables have been largely ignored. ${ }^{31}$ Integrating the findings of comparative political economy more thoroughly into international political economy research promises important and exciting new advances and deserves thus further attention. Both subfields would undoubtedly benefit from enhanced exchange of ideas and insights.

A case in point is the growing literature on transgovernmental networks (Slaughter, 1997; 2004; Raustiala, 2002). This literature is primarily concerned with how sub-national actors such as regulatory agencies cooperate across borders to supplement and at times supplant traditional means of international cooperation. Much of this work has focused on the types of networks that have emerged and their roles in various thematic settings (Slaughter, 2000). Questions about the origins of these networks, their varying relevance across issue areas, and the distribution of power within them have yet to be full y explored. Bridg ing the comparativist literature on bureaucratic autonomy with the work in International Relations and International Law on

\footnotetext{
${ }^{30}$ On the particular utility of case studies for theory development, see George 1979, Mahoney 2003, and Gerring 2004.

${ }^{31}$ Mattli and Büthe 2003 is an exception and is a promising effort to integrate the two fields.
} 
transgovernmental networks could speak powerfully to some of these questions. Dan Carpenter's work, for example, provides a detailed roadmap for explaining varying degrees of bureaucratic entrepreneurship at the domestic level (Carpenter, 2001). Applying his findings to the international setting would no doubt illuminate the causal processes at work in transgovernmental relations.

The argument presented also has interesting implications for policymakers and firms with stakes in international market competition. Its central insight is that international rules are constructed by those who have the ability to articulate, promote, and defend their regulations in the international arena. Th is ability depends on domestic regulatory institutions. Against this background, the widespread intuition of $b$ usiness lobbies that they should curtail domestic regulatory authority in order to minimize regulatory burdens seems short-sighted. The growing importance of i nternational economic governance even for domestically-focused companies should flip firm preferences. As com panies face rules settled internationally, they will have to fend off regulatory initiatives from foreign jurisdictions. Business has an incentive to externalize its familiar domestic regulatory environment in orde $r$ to minimize adjustment costs. Domestic regulators, which negotiate, monitor, and enforce many international market rules, then become the natural ally - and not enemy - of firms hoping to compete successfully in the international economy. Similarly, policymakers and legislators who $\mathrm{m}$ ay have op posed delegation of regulatory authority to powerful agencies in domestic settings may come to support such efforts as a mechanism to promote national interests in international economic debates. In light of the international importance of domestic regulatory institutions, a debate over the strategic mobilization of regulatory capacity to achieve competitive advantage could be just around the corner. 


\section{REFERENCES}

Aggarwal, V. K. 1985. Liberal protectionism: the international politics of organized textile trade. Berkeley: University of California Press.

Amable, B. 2000. Institutional complementarity and diversity of social systems of innovation and production. Review of International Political Economy, 7 (4): 645-87.

Bach, D. 2004. Varieties of Cooperation: Regulating Transnational Markets for Information Goods. Ph.D. Dissertation, Political Science, University of California, Berkeley.

Badaracco, J. L. J. 1985. Loading the Dice. Boston: Harvard Business School Press.

Bennett, C. J. 1992. Regulating Privacy: Data Protection and Public Policy in Europe and the United States. Ithaca: Cornell University Press.

Bhattacharya, U., and H. Daouk. 2002. The World Price of Insider Trading. Journal of Finance, 57 (1): 75-108.

Carlton, D. W., and D. R. Fischel. 1983. The Regulation of Insider Trading. Stanford Law Review, 35: 857-95.

Carpenter, D. 2001. The Forging of Bureaucratic Autonomy. Princeton, NJ: Princeton University Press.

Cerny, P. G. 1989. The 'Little Big Bang' in Paris: Financial Market De regulation in a di rigiste System. European Journal of Political Research, 17 (2): 169-92.

Cioffi, J. W. 20 02. Public Law and Private Power: The Comparative Political Economy of Corporate Governance in the United States and Germany. Ph.D. Di ssertation, Political Science, University of California, Berkeley.

Cohen, B. J. 2003. The Geopolitics of Currencies and the Fut ure of the International System. Paper prepared for $t$ he conference "The Geopol itics of Currencies and Oil", Real Instituto Elcano, Madrid, Spain, 7 November.

Council of Europe. 2004. National Laws 2003. Strasbourg: Council of Europe.

Cowhey, P., and J. Richards. 2000. Dialing for dollars: Institutional designs for the globalization of the market for basic telecommunications services. In Coping with Globalization, edited by Aseem Prakash and Jeffrey A. Hart. New York: Routledge, 148-69.

DeSombre, E. 1995. Baptists and bootleggers for the environment: The origins of United States unilateral sanctions. Journal of Environment \& Development, 4 (1): 53-75. 
DeSombre, E. 2 000. Domestic Sources of International Environmental Policy: Industry, Environmentalists, and U.S. Power. Cambridge: MIT Press.

Drezner, D. W. 2004 . Globalization, Coercion, and Competition: the different pathways to policy convergence. Paper prepared for the Annual Mee ting of the Internati onal Studies Association, Montreal, Canada, 17 March - 20 March.

Evans, P. B., D. Rueschemeyer, and T. Skocpol. 1985. On the Roa d to a More Adequate Understanding of the State. In Brining the State Back In, edited by Peter B. Evans, Diet rich Rueschemeyer and Theda Skocpol. Cambridge: Cambridge University Press, 347-66.

Farrell, H. 2003. Constructing the International Foundations of E-c ommerce: The EU-US Safe Harbor Arrangement. International Organization, 57 (2): 277-306.

Fedders, J. M., F. B. Wade, M. D. Mann, and M. Beizer. 1984. Waiver by Conduct - A Possible Response to the Internati onalization of Securities Markets. Journal of Comparative Business and Capital Market Law, 6 (1): 1-54.

Flaherty, D. H. 1 989. Protecting privacy in surveillance societies: the Federal Republic of Germany, Sweden, France, Canada, and the United States. Chapel Hill: University of North Carolina Press.

Fox, E. M. 19 97. Toward World Antitrust and Market Access. American Journal of International Law, 91 (1): 1-25.

Fox, E. M. 2 000. Competition law: linking the world. In Transatlantic Regulatory Cooperation: Legal Problems and Political Prospects, edited by George A. Bermann, Matthias Herdegen and Peter L. Lindseth. New York: Oxford University Press, 243-52.

Franda, M. 20 01. Governing the Internet: The Emergence of an International Regime. Boulder: Lynne Rienner.

George, A. L. 1979. Case Studies and Theory Development: The Method of Structured, Focused Comparison. In Diplomacy: New Approaches in History, Theory, and Policy, edited by Paul Gordon Lauren. New York: The Free Press, 43-68.

Gerring, J. 2004. What Is a Cas e Study and What Is It Good for? American Political Science Review, 98 (2): 341-54.

Gilardi, F. 2002. Policy credibility and delegation to independent regulatory agencies: a comparative empirical analysis. Journal of European Public Policy, 9 (6): 873-93.

Glassman, C. 2000. Customer Benefits from Current Information Sharing by Financial Services Companies. Washington: The Financial Services Roundtable. 
Glimstedt, H. 2001. Competitive Dynamics Of Technological Standardization: The Case Of Third Generation Cellular Communications. Industry and Innovation, 8 (1): 49-78.

Gruber, L. 2000. Ruling the world: power politics and the rise of supranational institutions. Princeton: Princeton University Press.

Haddock, D. D., and J. Macey, R. 1986. A Coasian Model of Insider Trading. Northwestern University Law Review, 80: 1449-72.

Hall, P. A., and D. W. Gi ngerich. 2002. Varieties of Capit alism and Instit utional Complementarities in the Macroeconomy: An Empirical Analysis. Paper prepared for the International Seminar on Institutional Complementarities and Dynamics of Economic Systems, Paris, France.

Hall, P. A., and D. Soski ce, eds. 2001. Varieties of Capitalism: The Institutional Foundations of Comparative Advantage. Oxford: Oxford University Press.

Hooghe, L., and G. Marks. 2000. Multi-level governance and European integration. Lanham: Rowman \& Littlefield.

Jabko, N. 2004. The Political Foundations of the Regulatory State. In The Politics of Regulation: Examining Regulatory Institutions and Instruments in the Age of Governance, edited by Jacint Jordana and David Levi-Faur. Northampton: Edward Elgar Publishing.

James, S. C., and D. A. Lake. 1989. The Second Face of Hegemony: Britain's Repeal of the Corn Laws and the American Walker Tariff of 1846. International Organization, 43 (1): 1-29.

Kagan, R. A. 200 1. Adversarial legalism: the American way of law. Cambridge: Harvard University Press.

Laurence, H. 1999. Spawning the SEC. Indiana Journal of Global Legal Studies, 6 (2): 647-83.

Longstreth, B. 1983. The SEC a fter fifty years: an ass essment of its past and future. Columbia Law Review, 83: 1593.

Lütz, S. 1998. The revival of the nation-state? Stock exchange regulation in an era of globalized financial markets. Journal of European Public Policy, 5 (1): 153-68.

Mahoney, J. 2003. Strategies of Causal Assessm ent in Comparative Historical Analysis. In Comparative Historical Analysis in the Social Sciences, edited by James Mahoney and Dietrich Rueschemeyer. Cambridge: Cambridge University Press, 337-72.

Manne, H. 1966. Insider Trading and the Stock Markets. New York: The Free Press. 
Mattli, W., and T. Büt he. 2003. Setting International Standards: Technological Rationality or Primacy of Power? World Politics, 56 (1): 1-42.

Milner, H. V. 1997. Interests, institutions, and information: domestic politics and international relations. Princeton: Princeton University Press.

Moran, M. 1 994. The State and the Financial Services Revolution: A Comparative Analysis. West European Politics, 17 (3): 158-77.

Newman, A. L. forthcoming 2005. Creating Privacy: the Politics of Personal Information in the United States and Europe. Ph.D. Dissertation, Political Science, University of California, Berkeley.

Newman, A. L., and D. Bach. 2004. Self-Regulatory Trajectories in the Shadow of Public Power: Resolving Digital Dilemmas in Europe and the United States. Governance, 17 (3): 387-413.

North, D., and B. Weingast. 1989. Constitutions and Commitment: The Evolution of Institutions Governing Public Choice in Seventeenth-Century England. Journal of Economic History, 49 (4): 803-32.

Oatley, T., and R. Nabors. 199 8. Redistributive Cooperation: Market Failure, Wealth Transfers, and the Basle Accord. International Organization, 52 (1): 35-54.

OECD. 2002. Measuring the Information Economy. Paris: Organization for Economic Cooperation and Development.

Pierson, P. 1993. When Effect Becomes Cause: Policy Feedback and Political Change. World Politics, 45 (4): 595-628.

Pierson, P. 2 000. Increasing Returns, Path Dependence, and the Study of Politics. American Political Science Review, 94: 251-67.

Pierson, P. 2004. Politics in Time: History, Institutions, and Social Analysis. Princeton: Princeton University Press.

Pollack, M. A., and G. C. Shaffer, eds. 2001. Transatlantic Governance in the Global Economy. Boulder: Rowman \& Littlefield.

Porter, M. E. 1990. The Competitive Advantage of Nations. New York: Free Press.

Posner, E. 2004. Market Power without a Single Market: The New Transatlantic Relations in Financial Services. Paper prepared for the workshop "The New Transatlantic Agenda and the Future of Transatlantic Economic Governance", Robert Schuman Centre for Advanced Studies, European Union Institute, Florence, Italy, 18 - 19 June. 
Putnam, R. D. 198 8. Diplomacy and Dom estic Politics: The Logic of Two-Level Games. International Organization, 42 (3): 427-60.

Raustiala, K. 2002. The Architecture of International Cooperation: Transgovernmental Networks and the Future of International Law. Virginia Journal of International Law, 43.

Richards, J. E. 19 99. Toward a Positive Theory of International Institutions: Regulating International Aviation Markets. International Organization, 53 (1): 1-37.

Schwartz, P. M., and J. R. Reidenberg. 1996. Data Privacy Law: Michie Publishing.

Shaffer, G. C. 2002. Reconciling Trade and Regulatory Goals: The Prospects and Limits of New Approaches to Transatlantic Governance Through Mutual Recognition and Safe Harbor Agreements. Columbia Journal of European Law, 9: 29.

Simitis, S. 1995. From the Market To the Polis: The EU Directive on the Protection of Personal Data. Iowa Law Review, 80: 445+.

Simmons, B. A. 199 9. The Internationalization of Ca pital. In Continuity and change in contemporary capitalism, edited by Herbert Kit schelt, Peter Lange, Gary Marks and John D. Stephens. Cambridge: Cambridge University Press, 36-69.

Simmons, B. A. 2001. The International Politics of Harmonization: The Case of Capital Market Regulation. International Organization, 55 (3): 589-620.

Singer, D. A. 20 04. Capital Rules: The Domestic Politics of International Regulatory Harmonization. International Organization, 58 (3): 531-66.

Skowronek, S. 1982. Building a new American state: the expansion of national administrative capacities, 1877-1920. Cambridge: Cambridge University Press.

Slaughter, A.-M. 1997. The Real New World Order. Foreign Affairs, 76: 183-97.

Slaughter, A.-M. 2000. Governing the Global Economy through Government Networks. In The role of law in international politics: essays in international relations and international law, edited by Michael Byers. Oxford: Oxford University Press, 177-205.

Slaughter, A.-M. 2004. A New World Order. Princeton: Princeton University Press.

Steinmo, S., K. Thelen, and F. Lo ngstreth, eds. 1992. Structuring politics: historical institutionalism in comparative analysis. Cambridge: Cambridge University Press.

Suttmeier, R. P., a nd Y.Xi angkui. 2004. China's Post-WTO Technology Policy: Standards, Software, and the Changing Nature of Techno-Nationalism. NBR Special Report. 
Swire, P. P., a nd R. E. Litan. 1998. None of your business: world data flows, electronic commerce, and the European privacy directive. Washington, D.C.: Brookings Institution Press.

Thelen, K. 1999. Historical Institutionalism in Co mparative Politics. In Annual Review of Political Science. Palo Alto: Annual Review Inc., 369-404.

Thelen, K. 200 3. How Institutions Evolve: Insights from Comparative Historical Analysis. In Comparative Historical Analysis in the Social Sciences, edited by James Mahoney and Dietrich Rueschemeyer. Cambridge: Cambridge University Press, 208-40.

Uncapher, M. 2 000. Global e-Data: Continental Divide - Will Europe Lag Behind the US? Arlington: Information Technology Association of America.

Vogel, D. 1986. National Styles of Regulation: Environmental Policy in Britain and the United States. Ithaca: Cornell University Press.

Vogel, D. 1995. Trading Up: Consumer and Environmental Regulation in a Global Economy. Cambridge: Harvard University Press.

Vogel, D. 1997. Trading up and g overning across: transnational governance and environmental protection. Journal of European Public Policy, 4 (4): 556-71.

Young, A. R. 2003. Political Transfer and "Trading Up": Transatlantic Trade in Genetically Modified Food and US Politics. World Politics, 55 (4): 457-84.

Zysman, J. 1994. How in stitutions create historically rooted trajectories of growth. Industrial and Corporate Change, 3 (1): 243-83. 
NOTAS

בx


NOTAS 